\title{
Cobalt Recovery from Waste Catalysts (Petroleum Refining Industry from Gujarat)
}

\author{
Palanivel Sivasakthi", Natarajan Sathaiyan \\ Department of Electro-Hydro Metallurgy, Central Electrochemical Research Institute, Karaikudi, India \\ Email: "sivachemist@rediffmail.com
}

Received December 30, 2011; revised February 2, 2012; accepted February 15, 2012

\begin{abstract}
A hydrometallurgical process has been developed for cobalt recovery from a waste catalyst (petroleum refining Industry). This waste catalyst containing about 2.18 weight \% of $\mathrm{Co}$, is highly contaminated by $\mathrm{Mg}, \mathrm{Al}, \mathrm{Si}, \mathrm{Ca}, \mathrm{Fe}, \mathrm{Ni}, \mathrm{Cu}$, $\mathrm{Zn}$, Mo. The major steps are: 1 ) The spent catalyst is roasted with flux material in an electrical furnace at very high temperature $\left(700^{\circ} \mathrm{C}\right)$ for a specific duration; 2$)$ The roasted sample is leached with sulphuric acid to bring the metal contents into solution form; 3) For separating cobalt values from the leach solution, the solution $\mathrm{pH}$ is raised by $\mathrm{NaOH}$ addition, where all cobalt content is precipitated at a $\mathrm{pH}$ of about 12;4) This cobalt hydroxide precipitate is filtered and dissolved in minimum amount of sulphuric acid to get cobalt sulphate solution which is used as the electrolyte for the electrolytic recovery of cobalt. For optimizing various parameters like 1) $\mathrm{H}_{2} \mathrm{SO}_{4}$ concentration; 2) Duration; 3) Cobalt concentration; 4) Current density; 5) Temperature; 6) Stirring etc. The particle surface morphology and deposited layers have been characterized by scanning electron microscopy (SEM). A compact metallic deposit containing $70 \%$ cobalt was obtained.
\end{abstract}

Keywords: Hydrometallurgical; Electrowinning; Cobalt; Flux Material; Waste Catalysts; $\mathrm{H}_{2} \mathrm{SO}_{4}$ Leaching

\section{Introduction}

Cobalt compounds have been used for centuries to impart a rich blue colour to glass, glazes and ceramics. Cobalt has been detected in Egyptian sculpture and Persian jewelry from the third millennium $\mathrm{BC}$, in the ruins of Pompeii (destroyed $\mathrm{AD}$ 76), and in China dating from the Tang dynasty (AD 618-907) and the Ming dynasty (AD 1368-1644). Cobalt glass ingots have been recovered from shipwrecks dating to the time of the Minoans.

Cobalt is a strategic and critical metal used in many diverse industrial applications [1,2]. Cathode cobalt is used primarily to make superalloys for gas turbine engines, but is also extensively used in chemicals, carbide and diamond tools and magnets [3]. In addition, cobalt finds application in medical implants, oil desulphurization, ceramics and the computer industry, each requiring high purity cathode cobalt which is $99.8 \%$ pure. It was stated that the production of refined cobalt in 1997 amounted to $24.471 \mathrm{t}$ from a product mixture of metal and chemicals.

Various forms of cobalt metal, including briquettes, cathode (electrolytic cobalt), fines, granules (shot), ingot, powder, and have been produced and marketed [4]. The most popular form is cathode cobalt involving sulfate

*Corresponding author. medium from a pressure leaching operation. Cobalt is typically associated with heavy metals such as nickel, zinc and copper; hence cobalt is usually extracted in small quantities as a byproduct from non-ferrous metal production. Most cobalt production is associated with nickel production from sulfide ores as well as laterites. Pressure leaching, solvent extraction followed by the electro winning of nickel and cobalt, is the preferred route for nickel and cobalt processing, replacing the reduction roasting and electrorefining process route. This processing route allows recovery rates of over $90 \%$ Co and $\mathrm{Ni}$ much higher than $50 \%$ for the reduction roasting route, much higher recovery rates of cobalt require novel technology in cobalt electrowinning.

The main media for cobalt electrowinning are sulfate or chloride solutions. In the electrowinning of cobalt from a sulfate solution, cobalt is deposited on the cathode coupled with oxygen evolution at the anode and in chloride solutions and the deposition is coupled with chlorine gas evolution at the anode, from chloride medium [5].

\section{Catalysts for the Petroleum and Chemical Industries}

Several cobalt compounds are used in several chemical reactions as catalysts [1]. Cobalt acetate is used for the 
production of terephthalic as well as dimethyl terephthalic acids, which are the key compounds for the production of PET. The steam reforming and hydrodesulfurization for the production of petroleum, which uses mixed cobalt-molybdenum aluminum oxides as catalyst is another important application. Cobalt and its compounds especially cobalt carboxylates, known as cobalt soaps are good oxidation catalysts. These are used in paints, varnishes, and ink as drying agents in which the oxidation of certain compounds leads to the drying. The same carboxylates are used to improve the adhesion of the steel to rubber in steel belted radial tires [1,2].

\section{Experimental}

Initially synthetic cobalt solution is employed for the electrolytic recovery. After optimizing various parameters like acid concentration, duration, cobalt concentration, current density, temperature, stirring etc., for maximum cobalt recovery, commercial waste Petroleum industry catalyst is used to recover cobalt content by roastingleaching step. From the leach solution cobalt was precipitated and redissolved in sulphuric acid which was used for electrolysis of cobalt recovery.

\subsection{Estimation of Cobalt in Electrolyte}

10 - $20 \mathrm{ml}$ (exactly measured) of cobalt solution is taken in $250 \mathrm{ml}$ conical flask. EDTA solution in excess over the amount of cobalt is added and then $5 \mathrm{ml}$ of buffer (pH5) and 3 - 5 drops of PAN indicator. The solution is diluted to about $100 \mathrm{ml}$ and titrated with the copper solution until the colour just change to violet at the end point $[6,7]$.

\subsection{Electrolytic Cell Set up}

The experiments are carried out in a $250 \mathrm{ml}$ glass beaker using cobalt sulfate and sulphuric acid as the electrolyte. The stainless steel is used as cathode (one side) while lead metal with silver as impurity (1\%) is used as the anode. Electrowinning experiments are carried out under different conditions to optimize various parameters for maximum cobalt recovery [5].

The electrodes are connected to the DC power supply (rectifier). The cathode is connected to the -ve terminal while anode is connected to the +ve terminal of the rectifier. The cell voltage between the two electrodes is measured employing a multimeter.

The cathode is polished one side insulated and weighed before electrolysis. After the electrolysis the cathode with cobalt deposit is removed from the cell, washed dried and accurately weighed. The difference in the cathode weight gives the weight of the cobalt deposited from which the current efficiency is calculated.

\section{Results and Discussion}

Cobalt is considered as a speciality metal. In India cobalt is mainly produced as by-product during the electrolytic recovery of copper and nickel. Cobalt is used for making: super alloys (for parts in aircraft engines), corrosion and wear resistant alloy, high speed stock, catalysts in petroleum industries cemented carbides and diamond tools, magnetic materials etc. [3].

In India cobalt consumption is more than its production. Hence to bridge the gap between production and consumption of cobalt, it is very important to recover cobalt from various secondary sources [8]. The cobalt sources mentioned above become secondary sources after their useful activity. One such example is waste catalyst used in petroleum industry for hydrodesulfurization of crude oil. The project work constitutes the recovery of cobalt from the waste catalyst of petroleum industries whose reported wt $\%$ is between $3 \%$ - 9\% depending on the source. In this investigation spent catalyst from Gujarat is employed as the raw material.

This spent catalyst mostly consists of Mo, Co, Ni, Fe, $\mathrm{Si}, \mathrm{Al}$ as their oxides. To bring the cobalt content into solution from the fine powder, spent catalyst $5 \mathrm{gm}$ of this powder catalyst is roasted with $10 \mathrm{gm}$ of flux material like sodium carbonate taken in a clay crucible, and heated in an electric furnace at $700^{\circ} \mathrm{C}$ for 3 hour duration where in this roasting unwanted impurities are removed as slags. The melt is removed, powdered and leached with $30 \% \mathrm{H}_{2} \mathrm{SO}_{4}$ solution for 60 minutes under stirring at $70^{\circ} \mathrm{C}$ and filtered. Since along with cobalt, nickel is also leached, this nickel is removed by adding $10 \%$ DMG (dimethyl glyoxime) solution to the filtrate to precipitate nickel as nickel-dimethyl glyoxime. This is warmed and the precipitate is filtered and the clear filtrate is made up to a known volume in a standard volumetric flask. Its cobalt content is estimated volumetrically and the solution is concentrated to raise the cobalt level to about 30 g/L Figure 1.

\begin{tabular}{cc}
\hline Elements & Weight percentage \\
\hline Mo & 5.33 \\
$\mathrm{Fe}$ & 0.47 \\
$\mathrm{Si}$ & 0.25 \\
$\mathrm{Al}$ & 18.38 \\
\hline
\end{tabular}

The optimizing various parameters like 1) $\mathrm{H}_{2} \mathrm{SO}_{4}$ concentration; 2) duration; 3) cobalt concentration; 4) $\mathrm{cu}-$ rrent density; 5) temperature and 6) stirring for maximum cobalt recovery through electrowinning and finally at these optimized conditions, cobalt metal is recovered from waste catalyst leach solution. 


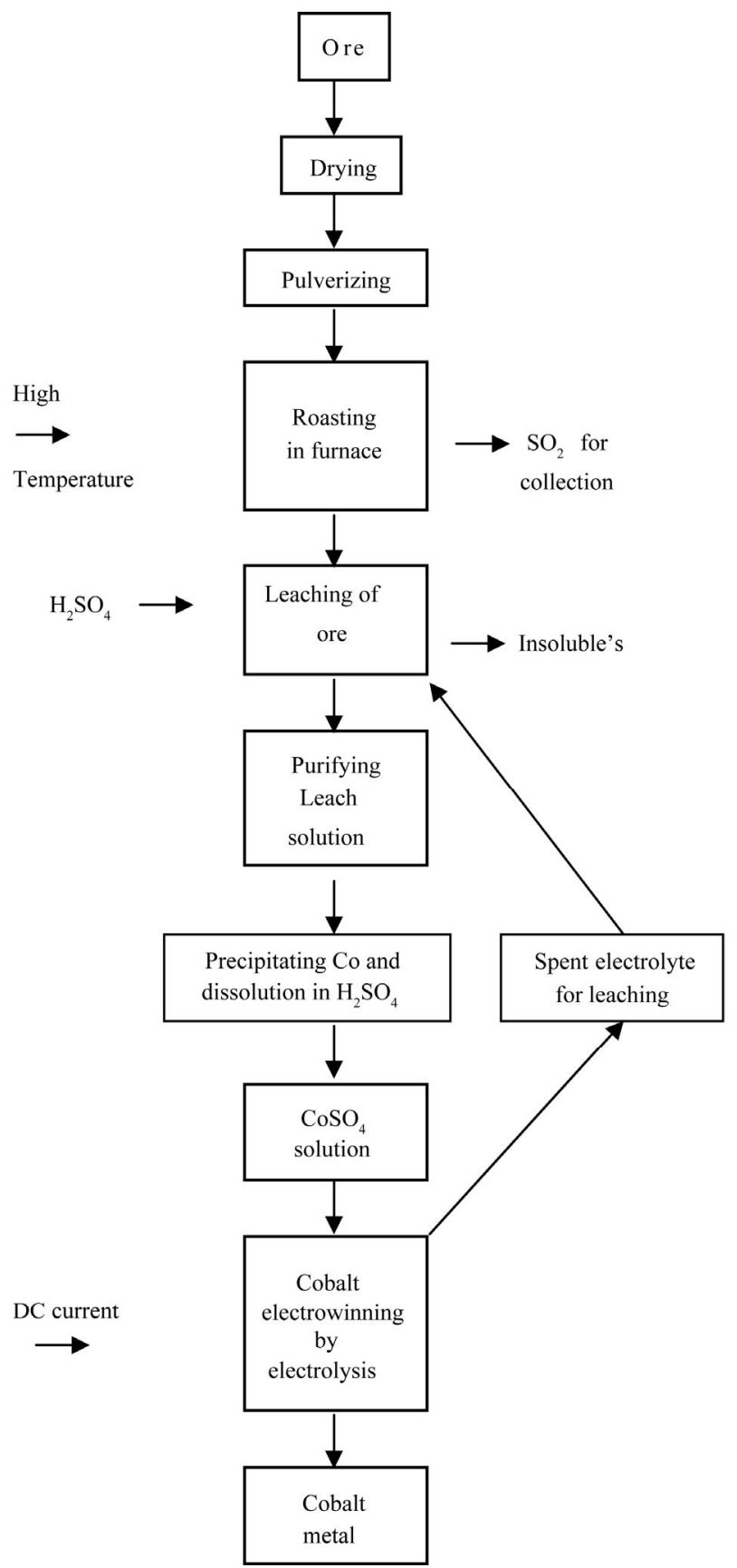

Figure 1. Flow chart on cobalt recovery.

\subsection{Effect of $\mathrm{H}_{2} \mathrm{SO}_{4}$ Concentration}

Effect of $\mathrm{H}_{2} \mathrm{SO}_{4}$ concentration on cobalt recovery from synthetic $30 \mathrm{~g} / \mathrm{L}$ Co as $\mathrm{CoSO}_{4}$ solution is given in Table 1 (Figure 2). The $\mathrm{H}_{2} \mathrm{SO}_{4}$ concentration studied is in the range of $0-100 \mathrm{~g} / \mathrm{L}$. As the $\mathrm{H}_{2} \mathrm{SO}_{4}$ concentration increases from 0 to $100 \mathrm{~g} / \mathrm{L}$ the current efficiency on cobalt recovery decreases from $85.5 \%$ to $14.2 \%$. The decrease in current efficiency may be due to the redissolution of cobalt deposit which increase with $\mathrm{H}_{2} \mathrm{SO}_{4}$ concentration. i.e. As the concentration of $\mathrm{H}_{2} \mathrm{SO}_{4}$ increases, decreases in
Table 1. Effect of acid concentration on cobalt electro winning.

\begin{tabular}{cccc}
\hline $\begin{array}{c}\mathrm{H}_{2} \mathrm{SO}_{4} \\
\text { concentration } \\
(\mathrm{g} / \mathrm{L})\end{array}$ & $\begin{array}{c}\text { Weight of Co } \\
\text { deposit }(\mathrm{g})\end{array}$ & $\begin{array}{c}\text { Current } \\
\text { efficiency } \\
(\%)\end{array}$ & $\begin{array}{c}\text { Mole } \\
\text { percent } \\
(\%)\end{array}$ \\
\hline 0 & 1.1111 & 85.5 & 0 \\
2.5 & 0.9946 & 76.5 & 2.55 \\
5 & 0.8031 & 61.5 & 5.10 \\
20 & 0.2982 & 22.9 & 20.41 \\
40 & 0.2044 & 15.6 & 40.81 \\
\hline
\end{tabular}

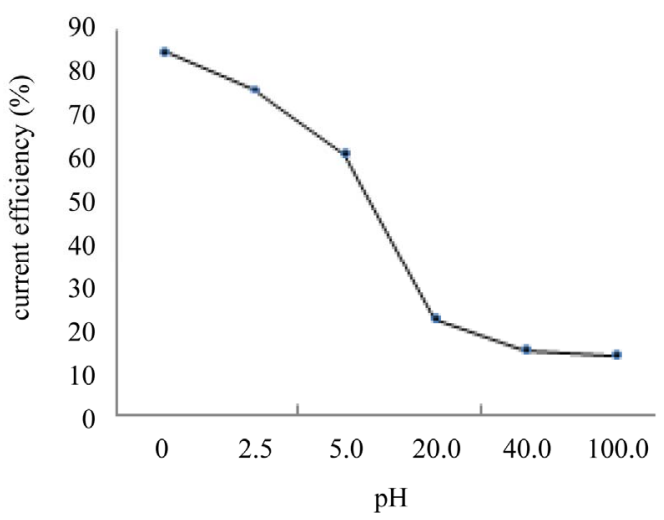

Figure 2. Effect of acid concentration $(\mathrm{pH})$ on cobalt recovery.

the current efficiency on cobalt recovery. Whereas, the concentration of $\mathrm{H}_{2} \mathrm{SO}_{4}$ is in $0 \mathrm{~g} / \mathrm{L}$, the current efficiency and deposition of cobalt recovery are raised at a maximum level.

For any electrolysis, the cell voltage is a critical factor and it is directly related to power consumption. Only this $5 \mathrm{~g} / \mathrm{L} \mathrm{H}_{2} \mathrm{SO}_{4}$ case has moderate cell voltage of $4.43 \mathrm{~V}$ and hence $5 \mathrm{~g} / \mathrm{L} \mathrm{H}_{2} \mathrm{SO}_{4}$ is taken as optimum concentration.

\subsection{Effect of Duration}

Table 2 and Figure 3 show the effect of duration (30 $180 \mathrm{~min}$ ) on cobalt recovery. All experiments are carried out at optimized $\mathrm{H}_{2} \mathrm{SO}_{4}$ concentration of $5 \mathrm{~g} / \mathrm{L}$. As the duration increases from 30 minute, the current efficiency for cobalt recovery also increases and it reaches a maximum value of $61.5 \%$ at 120 minutes duration after which the current efficiency starts decreasing. From this table it seems that 120 minutes duration is enough for the cobalt recovery under the specified electrolytic conditions and therefore 120 minutes is found to be optimum duration, In all theses cases cobalt metal foil in gray colour is deposited.

\subsection{Effect of Cobalt Concentration}

Effect of cobalt concentration (10 - 50 g/L) on cobalt 
Table 2. Effect of duration on cobalt electrowinning.

\begin{tabular}{ccc}
\hline Duration (min) & $\begin{array}{c}\text { Weight of Co } \\
\text { deposit (gm) }\end{array}$ & $\begin{array}{c}\text { Current } \\
\text { Efficiency (\%) }\end{array}$ \\
\hline 30 & 0.1466 & 11.2 \\
60 & 0.2812 & 21.6 \\
90 & 0.3649 & 28 \\
120 & 0.8031 & 61.5 \\
180 & 0.6693 & 51.4 \\
\hline
\end{tabular}

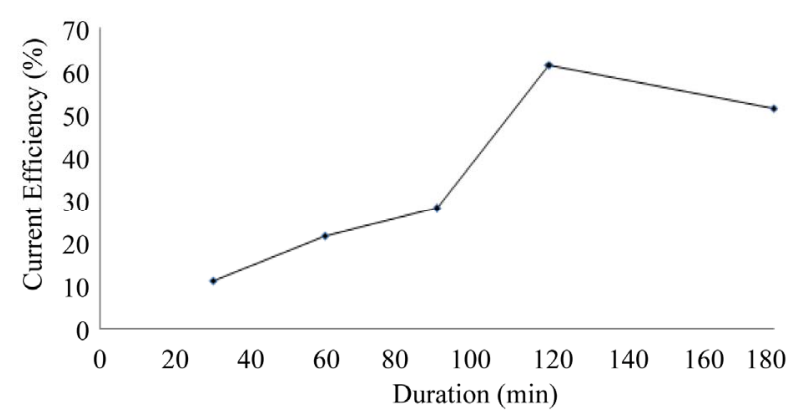

Figure 3. Effect of duration on cobalt recovery.

recovery is shown in Table 3 and Figure 4. As in expected with increase in cobalt concentration the current efficiency on cobalt recovery also increases and from this table $30 \mathrm{~g} / \mathrm{L}$ Co is chosen as best optimum level and above and below this there is a rise in all voltage, which may be due to decrease in conductivity of the electrolyte.

\subsection{Effect of Current Density}

Current density is directly related to production/recovery of product. Table $\mathbf{4}$ and Figure 5 show the effect of current density (150 - $400 \mathrm{~A} / \mathrm{M}^{2}$ ) on cobalt recovery.

Generally with low current density the rate of metal deposit will be less and hence at $150 \mathrm{~A} / \mathrm{M}^{2}$ current density, very low cobalt weight is observed with low current efficiency of $64.5 \%$. With increase in current density the metal recovery increases and therefore current efficiency increases. But after $200 \mathrm{~A} / \mathrm{M}^{2}$ case, the current efficiency decreases due to the more liberation of hydrogen gas at the cathode besides the cobalt metal deposition. Hence from this table, $200 \mathrm{~A} / \mathrm{M}^{2}$ is found to be optimum current density.

\subsection{Effect of Temperature}

The effect of temperature $\left(30^{\circ} \mathrm{C}-60^{\circ} \mathrm{C}\right)$ on cobalt recovery/current efficiency is provided in the Table 5 and Figure 6. At $30^{\circ} \mathrm{C}$, the current efficiency is $85.1 \%$. This reaches little high value of $97.4 \%$ at $60^{\circ} \mathrm{C}$. But for conducting experiments at $60^{\circ} \mathrm{C}$ more electric power is required. Hence in order to reduce cost of cobalt recovery, the room temperature $30^{\circ} \mathrm{C}$ is arrived as optimum temperature on cobalt recovery.
Table 3. Effect of cobalt concentration on cobalt electro winning.

\begin{tabular}{ccc}
\hline $\begin{array}{c}\text { Cobalt Concentration } \\
(\mathrm{g} / \mathrm{L})\end{array}$ & $\begin{array}{c}\text { Weight of Co } \\
\text { deposit (gm) }\end{array}$ & $\begin{array}{c}\text { Current efficiency } \\
(\%)\end{array}$ \\
\hline 10 & 0.5536 & 42.6 \\
20 & 0.6850 & 52.7 \\
30 & 0.8031 & 61.5 \\
40 & 1.1015 & 84.7 \\
50 & 1.6288 & 86.8 \\
\hline
\end{tabular}

Table 4. Effect of current density on cobalt electrowinning.

\begin{tabular}{cccc}
\hline $\begin{array}{c}\text { Current density } \\
\left(\mathrm{A} / \mathrm{M}^{2}\right)\end{array}$ & $\begin{array}{c}\text { Current } \\
(\mathrm{Amp})\end{array}$ & $\begin{array}{c}\text { Weight of Co } \\
\text { deposit (gm) }\end{array}$ & $\begin{array}{c}\text { Current } \\
\text { efficiency (\%) }\end{array}$ \\
\hline 150 & 0.3 & 0.4196 & 64.5 \\
200 & 0.4 & 0.7320 & 85.1 \\
250 & 0.5 & 0.785 & 72.7 \\
300 & 0.6 & 0.8031 & 61.5 \\
400 & 0.8 & 1.0312 & 60.6 \\
\hline
\end{tabular}

Table 5. Effect of temperature on cobalt electrowinning.

\begin{tabular}{ccc}
\hline $\begin{array}{c}\text { Tempe rature } \\
\left({ }^{\circ} \mathrm{C}\right)\end{array}$ & $\begin{array}{c}\text { Weight of Co } \\
\text { deposit }(\mathrm{gm})\end{array}$ & Current efficiency (\%) \\
\hline 30 & 0.7320 & 85.1 \\
40 & 0.7576 & 88 \\
50 & 0.8673 & 100 \\
60 & 0.8374 & 97.4 \\
\hline
\end{tabular}

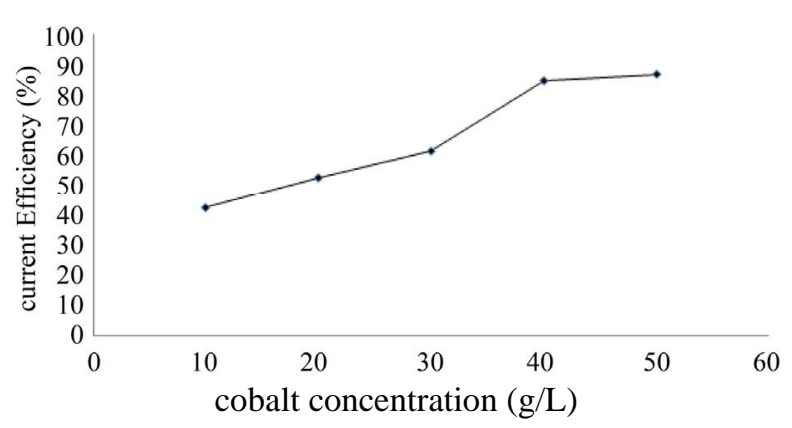

Figure 4. Effect of cobalt concentration on cobalt recovery.

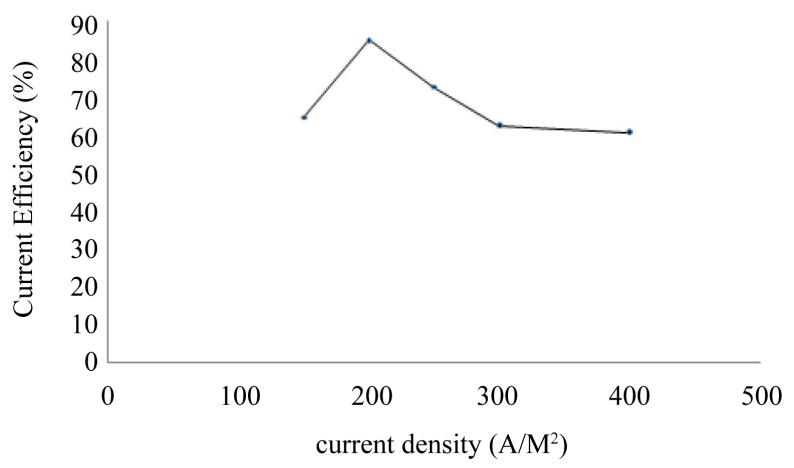

Figure 5. Effect of current density on cobalt recovery. 


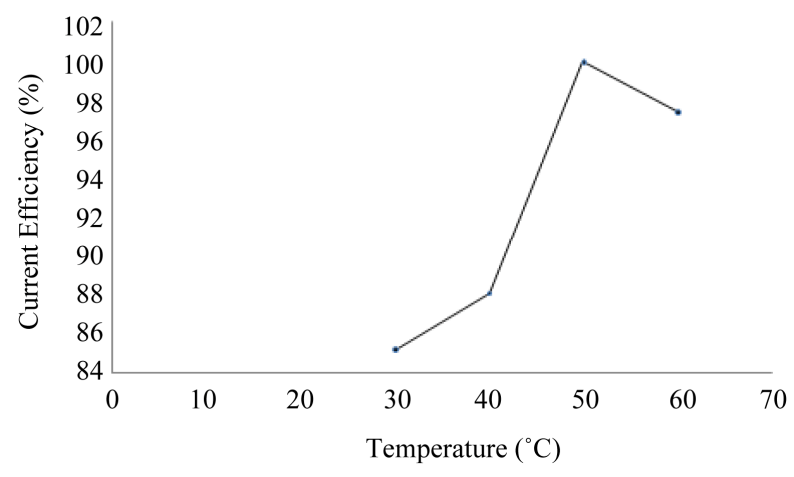

Figure 6. Effect of temperature on cobalt recovery.

\subsection{Effect of Stirring}

Since stirring/agitation has critical effect on current efficiency of cobalt recovery, effect of stirring between 0 700 RPM is carried out and the result is shown in Table 6 and Figure 7.

From the table it is observed that with increase in stirring the current efficiency is decreased Whereas, the 0 RPM of stirring, the current efficiency is high and deposition of cobalt recovery is also highest compared to other RPM condition which is an abnormal behaviour. This may be due to the redissolution of the cobalt deposit with increase of stirring. Hence solution need not be agitated for cobalt recovery under the specified electrolytic conditions. The optimum parameters for the electrowinning of cobalt is shown in Table 7.

\subsection{SEM (EDAX) Analysis and Characterization of Cobalt Deposit}

Figure 8 show the quantitative composition of waste catalyst by SEM (EDAX). From this figure the Co concentration is found to be $2.18 \mathrm{wt} \%$. Figures 9(a) and (b) show the SEM figures of waste catalyst before roastingleaching. Magnification is 100 in Figure 9(a) and it is 1000 in Figure 9(b). In both figures the white areas denote $\mathrm{Al}_{2} \mathrm{O}_{3}$ while the remaining grey and dark colours are due to the presence of other oxides. Figures 9(c) and (d) is the SEM figures of catalyst after roasting-leaching at different magnifications.

Figures 10(a) and (b) shows the SEM figure of cobalt deposit with $\mathrm{H}_{2} \mathrm{SO}_{4}$ and without $\mathrm{H}_{2} \mathrm{SO}_{4}$ respectively recovered at a current density of $300 \mathrm{~A} / \mathrm{M}^{2}$ in the electrolysis. In Figure 10(a) there are many small holes due to the liberation of $\mathrm{H}_{2}$ during $\mathrm{Co}$ deposit leading to decrease in current efficiency (value is: 61.5\%), while the Figure 9(b) has only few holes of $\mathrm{H}_{2}$ indicating high current efficiency (value is $85.5 \%$ ).

\section{Conclusions}

This project work is based on the recovery of cobalt from petroleum industry where it is used as hydrodesulphuri-

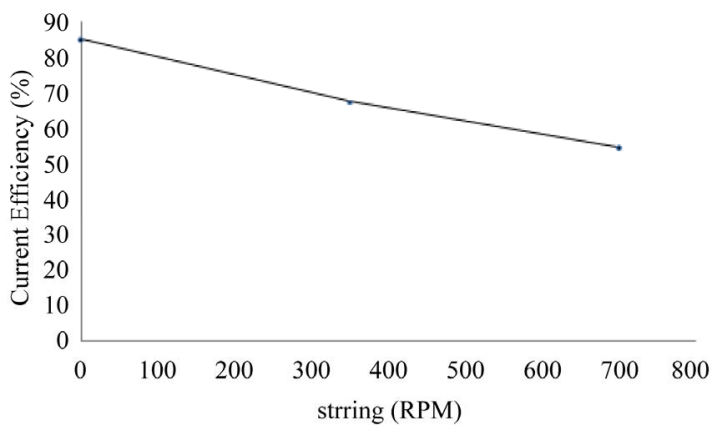

Figure 7. Effect of stirring on cobalt recovery.

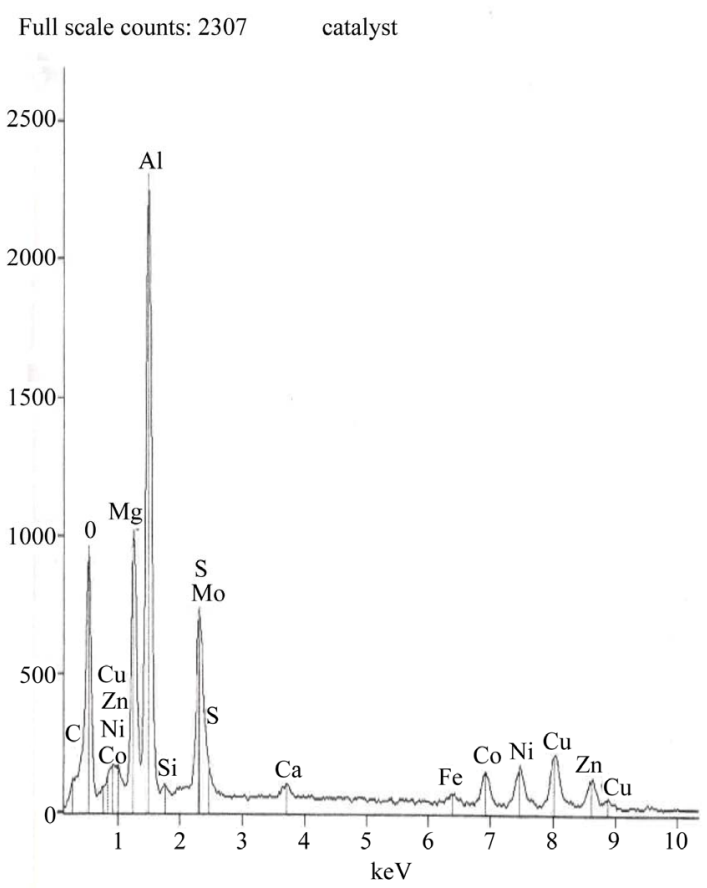

Quantitative Results catalyst

\begin{tabular}{lccccc}
\multicolumn{5}{c}{ Quantitative Results catalyst } \\
Element & Net & ZAF & Weight \% & Atom \% & Formula \\
& Counts & & & & \\
\hline $\mathrm{C}$ & 284 & 7.076 & 11.23 & 19.48 & $\mathrm{C}$ \\
$\mathrm{O}$ & 7821 & 4.450 & 39.24 & 51.09 & $\mathrm{O}$ \\
$\mathrm{Mg}$ & 9438 & 2.969 & 8.35 & 7.15 & $\mathrm{Mg}$ \\
$\mathrm{Al}$ & 23150 & 2.572 & 18.38 & 14.19 & $\mathrm{Al}$ \\
$\mathrm{Si}$ & 316 & 2.514 & 0.25 & 0.19 & $\mathrm{Si}$ \\
$\mathrm{S}$ & 4276 & 1.618 & 2.75 & 1.78 & $\mathrm{~S}$ \\
$\mathrm{Ca}$ & 735 & 1.209 & 0.44 & 0.23 & $\mathrm{Ca}$ \\
$\mathrm{Fe}$ & 502 & 1.123 & 0.47 & 0.18 & $\mathrm{Fe}$ \\
$\mathrm{Co}$ & 2026 & 1.145 & 2.18 & 0.77 & $\mathrm{Co}$ \\
$\mathrm{Ni}$ & 2583 & 1.129 & 3.10 & 1.10 & $\mathrm{Ni}$ \\
$\mathrm{Cu}$ & 3799 & 1.209 & 5.38 & 1.77 & $\mathrm{Cu}$ \\
$\mathrm{Zn}$ & 1626 & 1.214 & 2.89 & 0.92 & $\mathrm{Zn}$ \\
$\mathrm{Mo}$ & 6345 & 1.534 & 5.33 & 1.16 & $\mathrm{Mo}$ \\
$\mathrm{Total}$ & & & 100.00 & 100.00 & \\
\hline
\end{tabular}

Figure 8. Quantitative composition of waste catalyst by SEM (EDAX). 

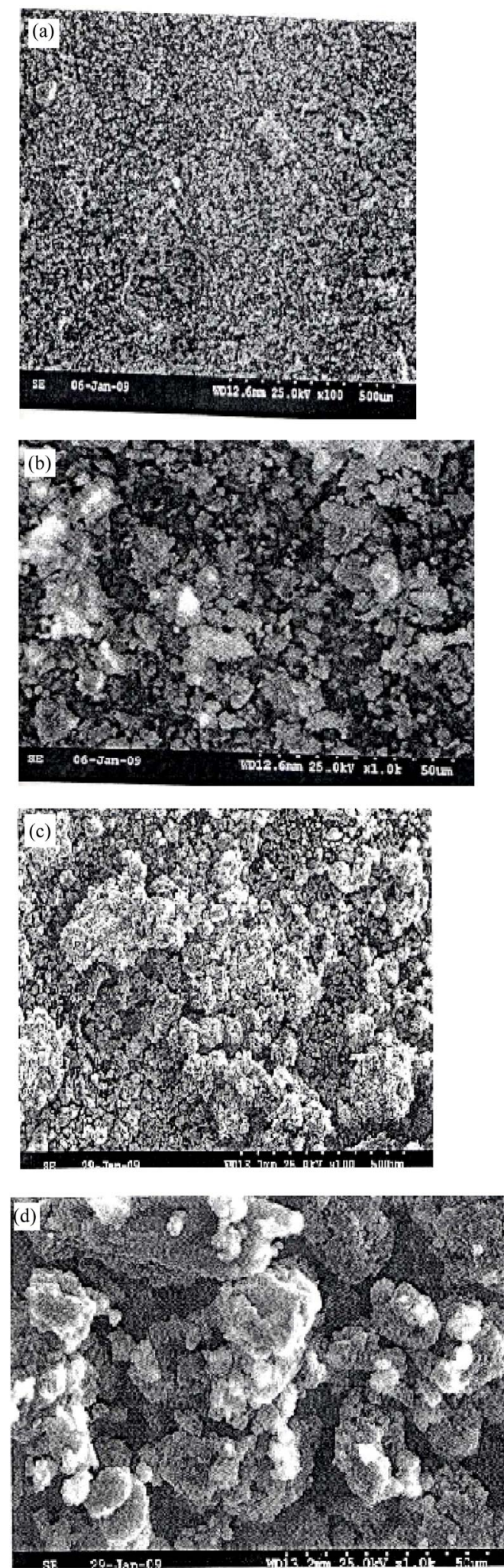

Figures 9. SEM figure of (a) waste catalyst $(\times 100$ magnification) before roasting; (b) waste catalyst $(\times 1000$ magnification) before roasting; (c) waste catalyst ( $\times 100$ magnification) after roasting-leaching; (d) waste catalyst $(\times 1000$ magnification) after roasting-leaching.
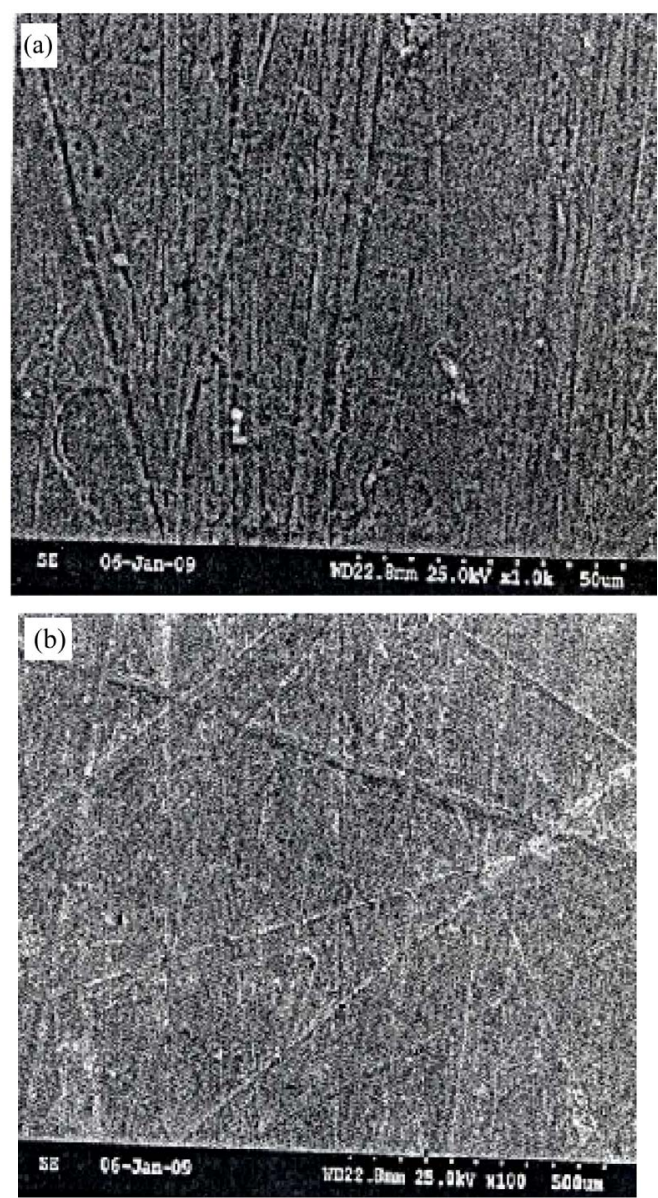

Figures 10. SEM figures of (a) Co deposit (with $\mathrm{H}_{2} \mathrm{SO}_{4}$ in bath) at $300 \mathrm{~A} / \mathrm{M}^{2}$ current density; (b) Co deposit (without $\mathrm{H}_{2} \mathrm{SO}_{4}$ in bath) at $300 \mathrm{~A} / \mathrm{M}^{2}$ current density.

Table 6. Effect of stirring on cobalt electrowinning.

\begin{tabular}{ccc}
\hline Stirring (RPM) & $\begin{array}{c}\text { Weight of Co } \\
\text { deposit (gm) }\end{array}$ & Current efficiency (\%) \\
\hline 0 & 0.7320 & 85.1 \\
350 & 0.5803 & 67.5 \\
700 & 0.4712 & 54.7 \\
\hline
\end{tabular}

Table 7. Optimum electrowinning parameters.

\begin{tabular}{cccc}
\hline \multicolumn{2}{c}{ Different parameters } & $\begin{array}{c}\text { Weight of } \\
\text { cobalt deposit } \\
\text { (gm) }\end{array}$ & $\begin{array}{c}\text { Current } \\
\text { efficiency } \\
(\%)\end{array}$ \\
\hline $\mathrm{H}_{2} \mathrm{SO}_{4}$ concentration & $5 \mathrm{~g} / \mathrm{L}$ & 0.8031 & 61.5 \\
Duration & $120 \mathrm{~min}$ & 0.8031 & 61.5 \\
Cobalt concentration & $30 \mathrm{~g} / \mathrm{L}$ & 0.8031 & 61.5 \\
Current density & $200 \mathrm{~A} / \mathrm{M}^{2}$ & 0.7320 & 85.1 \\
Temperature & $30{ }^{\circ} \mathrm{C}$ & 0.7320 & 85.1 \\
Stirring & $\mathrm{Nil}$ & - & - \\
\hline
\end{tabular}


zation catalyst for the purification of petroleum oil. (like removal of sulphur/addition of hydrogen)

Cobalt recovery from synthetic cobalt solutions are studied and the optimized values for these parameters for the specified electrolytic condition are $\mathrm{H}_{2} \mathrm{SO}_{4}$ concentration: $5 \mathrm{~g} / \mathrm{L}$ (2.13 pH), Duration: 120 minutes, Cobalt concentration: $30 \mathrm{~g} / \mathrm{L}$, Current density: $200 \mathrm{~A} / \mathrm{M}^{2}$, Temperature: $30^{\circ} \mathrm{C}$, Stirring: Nil.

At the optimized conditions, cobalt metal foil is electrolytically recovered (about 70\%) from the waste catalyst roasted leached solution (after concentration).

\section{Acknowledgements}

This work was supported by the Department of EHM division, Central Electrochemical Research Institute, Karaikudi-630 006, Government of India.

\section{REFERENCES}

[1] N. L. Piret, "Enhancing Cobalt Recovery from Primary and Secondary Resources," Journal of the Minerals, Metals and Materials Society, Vol. 50, No. 10, 1998, pp. 42-43. doi:10.1007/s11837-998-0351-1

[2] M. J. Hawkins, "Recovering Cobalt from Primary and Secondary Sources," Journal of the Minerals, Metals and Materials Society, Vol. 50, No. 10, 1998, pp. 46-50. doi:10.1007/s11837-998-0353-z

[3] S. J. Wang, "Cobalt-Its Recovery, Recycling and Application," Journal of the Minerals, Metals and Materials Society, Vol. 58, No. 10, 2006, pp. 47-50. doi:10.1007/s11837-006-0201-y

[4] P. Searle, "Forecasting the Cobalt Market through 2015," Journal of the Minerals, Metals and Materials Society, Vol. 50, No. 10, 1998, pp. 42-43. doi:10.1007/s11837-998-0352-0

[5] S. C. Das and T. Subbaiah, "Electrowinning of Cobalt, Winning from Pure Cobalt Sulphate Bath,” Hydrometallurgy, Vol. 12, No. 3, 1984, pp. 317-333. doi:10.1016/0304-386X(84)90004-5
[6] A. I. Vogel, “A Text Book of Quantitative Inorganic Analysis Including Elementary Instrumental Analysis,” The English Language Book Society and Longman, London, 1978, pp. 569-573.

[7] H. A. Flaschka, "EDTA Titrations, an Introduction to Theory and Practice,” Pergamon Press, London, 1964.

[8] R. P. Das, "Recovering Cobalt from Secondary Sources in India," Journal of the Minerals, Metals and Materials Society, Vol. 50, No. 10, 1998, pp. 46-50. doi:10.1007/s11837-998-0354-y

[9] I. M. Valverde Jr., J. F. Paulino and J. C. Afonso "Hydrometallurgical Route to Recover Molybdenum, Nickel, Cobalt and Aluminum from Spent Hydro Treating Catalyst in Sulphuric Acid Medium," Journal of Hazardous Materials, Vol. 160, No. 2-3, 2008, pp. 310-317. doi:10.1016/j.jhazmat.2008.03.003

[10] V. S. Bagotzky, "Fundamentals of Electrochemistry,” Plenum Press, New York, 1993, p. 404.

[11] Elsevier, "Metal Finishing Guidebook and Dictionary," Elsevier Science Publication, New York, Published Annually.

[12] A. Brenner, "Electrodeposition of Alloys, Principles and Practice,” Academic Press, New York, 1963.

[13] B. B. Kar, B. V. R. Murthy and V. N. Misra, "Extraction of Molybdenum from Spent Catalyst by Salt-Roasting," International Journal of Mineral Processing, Vol. 76, No. 3, 2005, pp. 143-147. doi:10.1016/j.minpro.2004.08.017

[14] R. G. Busnardo, N. G. Busnardo, G. N. Salvato and J. C. Afoxiso, "Processing of Spend NiMo and $\mathrm{CoMo} / \mathrm{Al}_{2} \mathrm{O}_{3}$ Catalysts via Fusion with $\mathrm{KHSO}_{4}$," Journal of Hazardous Materials, Vol. 139, No. 2, 2007, pp. 391-398.

[15] C. Kargl-Simard, J. H. Huang and A. M. Alfantazi, "Electrical Conductivity and Density of $\mathrm{CoSO}_{4} / \mathrm{H}_{2} \mathrm{SO}_{4}$ Solutions in the Range of Modern Cobalt Electrowinning Electrolytes,” Minerals Engineering, Vol. 16, No. 6, 2003, pp. 529-535. doi:10.1016/S0892-6875(03)00059-1

[16] W. J. Basirun, W. J. Basirun and Y. Alias, "Influence of Magnetic Field of the Electro Deposition of Ni-Co Alloy,” Journal of Chemical Sciences, Vol. 122, No. 2, 2010, pp. 279-285. doi:10.1007/s12039-010-0032-9 